\title{
Lithium and Beryllium abundances in peridotitic, pyroxenitic and eclogitic mantle assemblages
}

Seitz, H.-M., Woodland, A.B

Mineralogisches Institut, Universität Heidelberg, Im Neueneheimer Feld 236, 69120 Heidelberg, Germany

\section{Introduction}

Magmatic processes such as e.g. partial melting, crystal fractionation and mantle metasomatism variably modify the inventory of lithium and beryllium in the lithospheric mantle. During these processes $\mathrm{Li}^{+}$is likely to behave as a moderately incompatible element because $\mathrm{Li}^{+}$has a similar ionic radius to $\mathrm{Mg}^{2+}$ or $\mathrm{Fe}^{2+}$ which permits a coupled substitution in olivine, pyroxenes and garnet, potentially with trivalent cations, such as $\mathrm{Al}^{3+}, \mathrm{Fe}^{3+}, \mathrm{Cr}^{3+}, \mathrm{Sc}^{3+}$, $\mathrm{V}^{3+}$ and $\mathrm{REE}^{3+}$. From ionic radius and ionic charge considerations, $\mathrm{Be}^{2+}$ is expected to be strongly incompatible.

We have undertaken a detailed study of the $\mathrm{Li}$ and $\mathrm{Be}$ abundances in olivine, orthopyroxene, clinopyroxene, garnet and spinel from various mantle lithologies and tested their partitioning behavior as a function of $\mathrm{P}, \mathrm{T}$ and bulk composition. Over 17 well equilibrated spinel- and garnet-peridotite, garnet-pyroxenite and eclogite samples $\left(800^{\circ}-1400^{\circ} \mathrm{C}\right.$ and $\left.10-38 \mathrm{kbar}\right)$ were analyzed by Secondary Ion Mass Spectromety (SIMS). These mantle xenoliths (from the East Afican Rift, Massif Central, Mongolia, Vitim \& Pali Aiki) establish a baseline with which to compare samples from the Finero and several Pyrenean massifs that have been metasomatically overprinted (Seitz \& Woodland, in prep.).

In addition we investigated eclogitic samples from Roberts Victor and Obnazhënnaya (Russia) which are believed to have mantle origin (group A eclogites).

\section{Analytical Technique}

Analyses of $\mathrm{Li}$ and Be were accomplished using a modified CAMECA 3f-IMS ion microprobe at the Mineralogisches Institut, Universität Heidelberg. Analyses were made using a ${ }^{16} \mathrm{O}^{-}$ primary beam at an acceleration voltage of $12.5 \mathrm{kV}$. A focused beam with an intensity of 10 nA gave a beam diameter of $\approx 20-25 \mu \mathrm{m}$. Samples were coated with a layer of gold $\mathrm{ca} .50$ $\mathrm{nm}$ thick. Positive secondary ions were accelerated through a nominal $4.5 \mathrm{kV}$. The energy window was set to $40 \mathrm{eV}$. We employed energy filtering technique with an offset of $-75 \mathrm{~V}$ combined with a mass resolution of $\approx 800$. The combination of these two techniques surpresses interfering molecules, discriminates between element peaks, such as ${ }^{9} \mathrm{Be}$ and ${ }^{27} \mathrm{Al}^{3+}$, and minimizes the matrix effects (Ottolini et al. 1993). Ion yields of ${ }^{7} \mathrm{Li}$ and ${ }^{9} \mathrm{Be}$, were normalized to ${ }^{30} \mathrm{Si}$ for silicates and to ${ }^{26} \mathrm{Mg}$ for spinel. A NIST SRM-610 glass was used as a primary standard. Major element peaks $\left({ }^{30} \mathrm{Si}\right.$ and ${ }^{26} \mathrm{Mg}$ ) were measured for $2 \mathrm{sec}$ and 8 sec were applied for ${ }^{7} \mathrm{Li}$ and ${ }^{9} \mathrm{Be}$. Long term reproducibility of the SRM-610 standard is within $10 \%$. In run precision is $2-15 \%$ for ${ }^{7} \mathrm{Li}$ and $5-20 \%$ for ${ }^{9} \mathrm{Be}$.

\section{Results}

Lithium abundances vary with bulk chemistry. Pyroxenes from peridotitic xenoliths have $\mathrm{Li}$ concentrations on the order of several hundred ppb, while pyroxenes from pyroxenites have somewhat higher abundances (1-3 ppm with a maximum of $21 \mathrm{ppm}$ ). Clinopyroxenes from eclogites have $\mathrm{Li}$ concentrations comparable to those from peridotites $(400-970 \mathrm{ppb})$. $\mathrm{Li} \mathrm{in}$ spinels from different localities is greatly variable with abundances, ranging from concentrations below the detection limit $(<1 \mathrm{ppb})$ up to $750 \mathrm{ppb}$. Garnets from peridotites and pyroxenites contain $\leq 120 \mathrm{ppb} \mathrm{Li}$, whereas those from eclogites have up to $430 \mathrm{ppb} \mathrm{Li}$.

$\mathrm{Li}$ is preferentially incorporated into olivine, typically ranging between 1 and $4 \mathrm{ppm}$. The following partitioning relationship has been established: ol $>\mathrm{cpx} \geq \mathrm{opx}>>$ grt for grtperidotites, ol $>$ cpx $\geq$ opx $>>$ sp for sp-peridotites, $c p x \geq$ opx $>$ grt for grt- pyroxenites and cpx $>$ grt for eclogites. Similar relationships have been observed for sp-peridotites by Ottolini \& McDonough (1996). Partition coefficients for Li range between 0,4-1,1 for opx/cpx, 1,5 2,8 for ol/cpx and $0,06-0,4$ for grt/cpx (Fig. 1). 

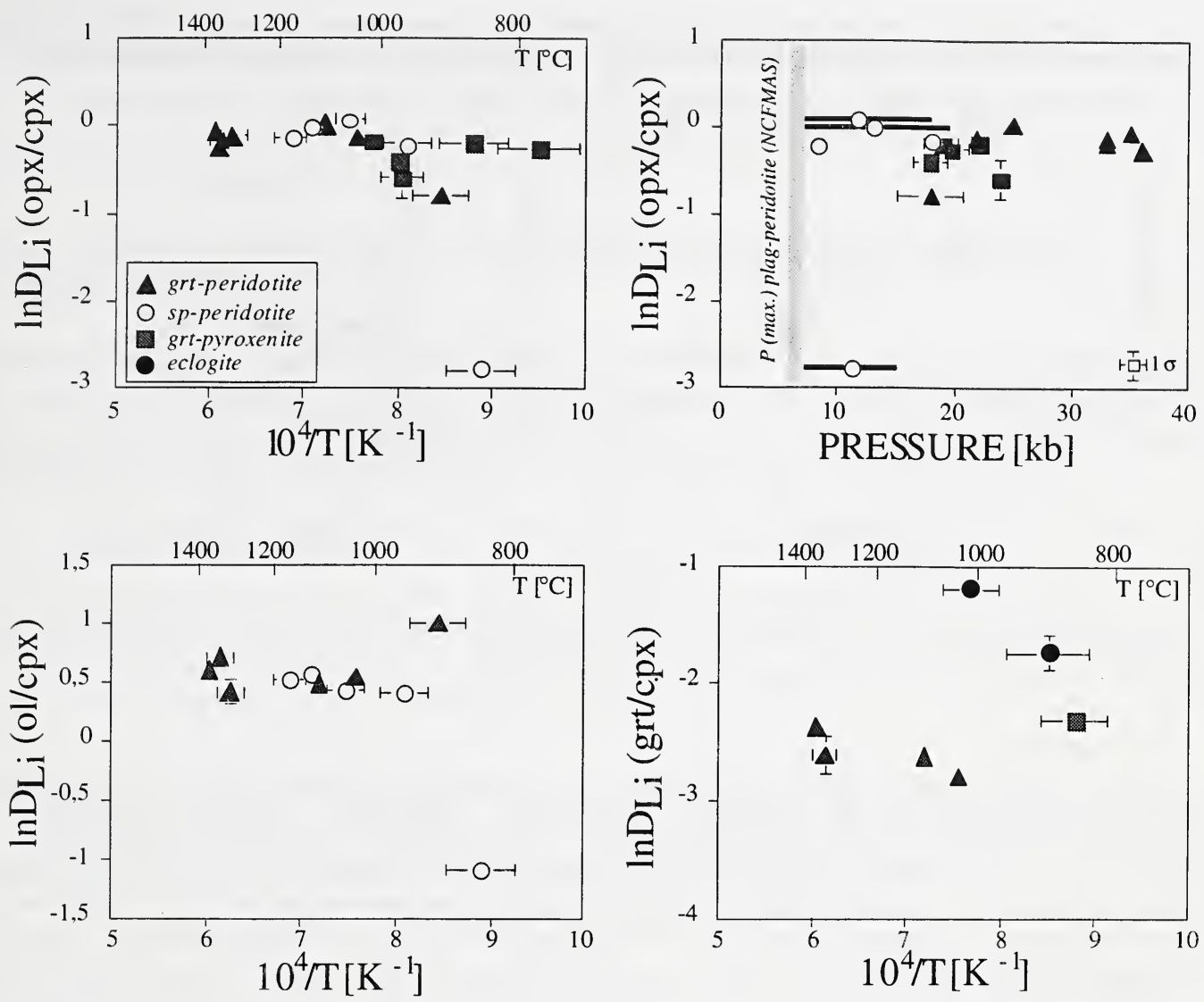

Fig. 1: Temperatures were calculated using thermometers of Brey \& Köhler (1990) and Krogh (1988). For grt-bearing samples, the pressure was determined with the Al-in-opx barometer of Brey \& Köhler (1990) and for sp-peridotites pressure was estimated using the barometer of Webb \& Wood (1986) giving P max. Ca-in-olivine barometer of Köhler \& Brey (1990) was applied to 2 samples. Minimum pressure is constrained by the plag- to sp-peridotite transition in the NCFMAS-system (min. to max. pressures are indicated by black bars).

It has been shown that trace element partitioning can be strongly temperature or pressure dependent, and compositional effects have also to be encountered (e.g. Stosch, 1981; Seitz \& Altherr, 1996). However, partition coefficients for $\mathrm{Li}$ between opx/cpx, ol/cpx and grt/cpx show no dependency upon $\mathrm{P}$ or $\mathrm{T}$. With the exception of one amph-sp-peridotite, $\mathrm{D}_{\mathrm{Li}}$ (opx/cpx), for example, exhibits only a limited range; typically 0.7 and 1 (Fig. 1).

Preliminary data from metasomatized peridotites and pyroxenites from Finero and several Pyrenean massifs show enrichment of $\mathrm{Li}$ in pyroxenes and olivine, whereby $\mathrm{Li}$ is preferentially incorporated into clinopyroxene (cpx > ol $>$ opx). Calculated Li concentration ratios (opx/cpx and ol/cpx) are significantly lower in these samples compared with 'normal' unmetasomatized peridotites and pyroxenites, suggesting disequilibrium. Thus the Li ratios can only be considered as an indicator of metasomatism rather than being meaningful partition coefficients.

Beryllium concentrations in opx and cpx range between 10 and $150 \mathrm{ppb}$ and are close to the detection limit in olivine $(\approx 2-8 \mathrm{ppb})$. Beryllium abundances in the garnets and spinels investigated here are at or below the detection limit. Partitioning of $\mathrm{Be}$ in pyroxenites and peridotites exhibit following relationship: $\mathrm{cpx}>\mathrm{opx}>>$ ol. The partitioning of Be shows no $\mathrm{P}$ 
or $\mathrm{T}$ dependency for ol/cpx but clearly correlates with temperature for opx/cpx (Fig. 2). The ionic radius of $\mathrm{Be}$ is similar to that of $\mathrm{Si}$, suggesting substitution of $\mathrm{Be}$ on the tetrahedral site.
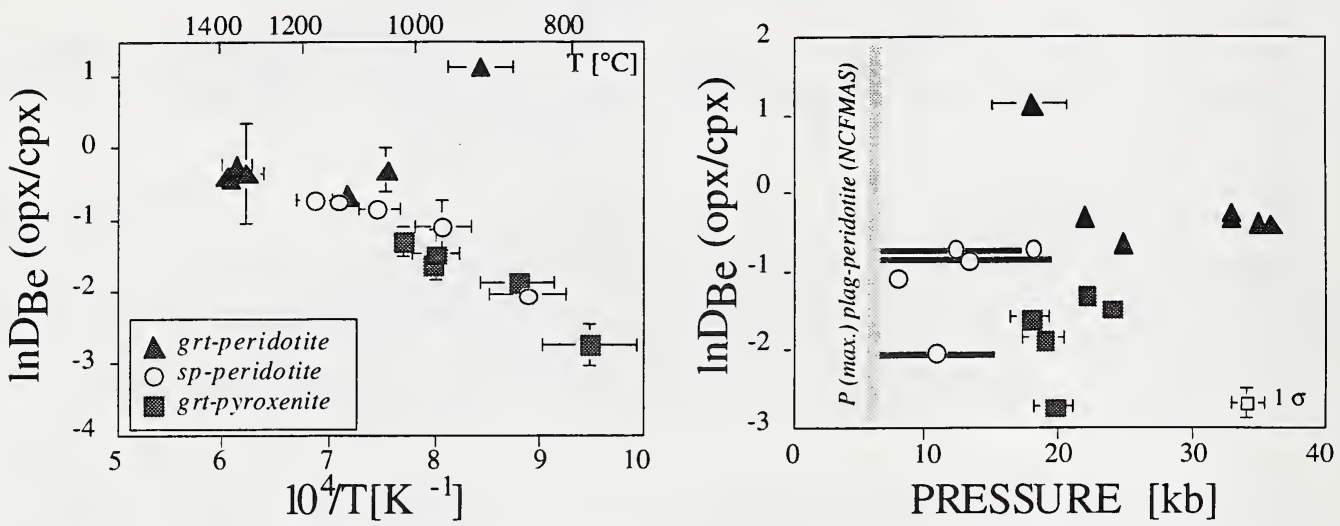

Fig. 2: $\ln D_{\mathrm{Be}} \mathrm{opx} / \mathrm{cpx}$ as a function of temperature and pressure (see Fig. 1 for more detailed descriptions).

\section{Conclusions}

Low Li-abundances in mantle peridotites and pyroxenites emphasize it's incompatibility during partial melting and fractional crystallization, respectively. However, elevated Liconcentrations are present in some pyroxenites, presumably due to complete crystallization of such partial melts. Disequilibrium is manifested by preferential enrichment of $\mathrm{Li}$ in cpx. Since the absolute and intercrystalline partitioning of $\mathrm{Li}$ is independent of $\mathrm{T}, \mathrm{P}$ and bulk composition, $\mathrm{Li}$ appears to be a suitable tracer element for chemical processes such as metasomatism.

Our data set indicates that under upper mantle conditions the partitioning of $\mathrm{Be}$ has a strong dependence on $\mathrm{T}$ and to a lesser extend on $\mathrm{P}$.

\section{References}

Brey, G. P., and Köhler, T., 1990, Geothermobarometry in four-phase lherzolites II. New thermobarometers, and practical assesment of existing thermobarometers: J. Petrol., v. 31, p. 1353-1378.

Köhler, T. P., and Brey, G. P., 1990, Calcium exchange between olivine and clinopyroxene calibrated as a geothermobarometer for natural peridotites from 2 to $60 \mathrm{~kb}$ with applications.: Geochim. Cosmochim. Acta, v. 54, p. 2375-2388.

Krogh, E. J., 1988, The garnet-clinopyroxene Fe-Mg geothermometer - a reinterpretation of existing experimental data: Contrib. Mineral. Petrol., v. 99, p. 44-48.

Ottolini, L., Bottazzi, P., and Vannucci, R., 1993, Quantification of Lithium, Beryllium, and Boron in silicates by Secondary Ion Mass Spectrometry using conventional energy filtering: Anal. Chem., v. 65, p. 1960-1968.

Ottolini, 1., and McDonough, W. F., 1996, Geochemistry of Lithium and Boron in the Mantle: Results from studies of peridotites: Journal of Conference Abstracts (Goldschmidt Conference), v. 11, p. 446.

Seitz, H.-M., and Altherr, R., 1996, Partitioning of Transition Metal Elements Between Mantle Minerals: Empirical Geothermobarometers.: Journal of Conference Abstracts, v . 1, p. 555.

Stosch, H.-G., 1981, Sc, Cr, Co and Ni partitioning between minerals from spinel peridotite xenoliths: Contrib. Mineral. Petrol., v. 78, p. 166-174.

Webb, S. A. C., and Wood, B. J., 1986, Spinel-pyroxene-garnet relationships and their dependence om Cr/Al ratio.: Contrib. Mineral. Petrol., v. 92, p. 471-480. 